\title{
Immune function and parasite resistance in male and polymorphic female Coenagrion puella Gerrit Joop $^{1,2}$, Andreas Mitschke 3 , Jens Rolff*2 and Michael T Siva-Jothy²
}

\author{
Address: ${ }^{1}$ Zoologisches Institut, AG Ökologie, Technische Universität Braunschweig, Braunschweig, Germany, ${ }^{2}$ Department of Animal and Plant \\ Sciences, University of Sheffield, Sheffield, UK and 3 Institut für Mikrobiologie, Technische Universität Braunschweig, Braunschweig, Germany \\ Email: Gerrit Joop - g.joop@tu-bs.de; Andreas Mitschke - a.mitschke@tu-bs.de; Jens Rolff* - jor@sheffield.ac.uk; Michael T Siva-Jothy - m.siva- \\ jothy@sheffield.ac.uk \\ * Corresponding author
}

Published: 07 March 2006

BMC Evolutionary Biology2006, 6:19 doi:10.1186/147|-2148-6-19
Received: 13 July 2005

Accepted: 07 March 2006

This article is available from: http://www.biomedcentral.com/|47|-2/48/6/19

(c) 2006Joop et al; licensee BioMed Central Ltd.

This is an Open Access article distributed under the terms of the Creative Commons Attribution License (http://creativecommons.org/licenses/by/2.0), which permits unrestricted use, distribution, and reproduction in any medium, provided the original work is properly cited.

\begin{abstract}
Background: Colour polymorphisms are widespread and one of the prime examples is the colour polymorphism in female coenagrionid damselflies: one female morph resembles the male colour (andromorph) while one, or more, female morphs are described as typically female (gynomorph). However, the selective pressures leading to the evolution and maintenance of this polymorphism are not clear. Here, based on the hypothesis that coloration and especially black patterning can be related to resistance against pathogens, we investigated the differences in immune function and parasite resistance between the different female morphs and males.
\end{abstract}

Results: Our studies of immune function revealed no differences in immune function between the female morphs but between the sexes in adult damselflies. In an experimental infection females infected shortly after emergence showed a higher resistance against a fungal pathogen than males, however female morphs did not differ in resistance. In a field sample of adult damselflies we did not find differences in infection rates with watermites and gregarines.

Conclusion: With respect to resistance and immune function 'andromorph' blue females of Coenagrion puella do not resemble the males. Therefore the colour polymorphism in coenagrionid damselflies is unlikely to be maintained by differences in immunity.

\section{Background}

Colour polymorphisms are widespread and prominent in several taxa such as coral reef fish [1], birds [2] and tree frogs [3]. In many cases the genetic basis has been investigated $[1,4]$. However, the nature of selection pressures maintaining such polymorphisms are rarely known. One exception is a study on the pea aphid Acyrthosiphon pisum. In this species, both red and green colour morphs occur; these morphs differ in their susceptibility against natural enemies [5]. Polymorphisms can also be maintained by sexual selection, as suggested for plumage coloration in some birds [6] and in guppies [7]. Three major explanations have been proposed to explain the evolution and maintenance of such polymorphisms: frequency-dependent selection, heterozygote advantage [8] and environmental fluctuations. The last case has been elaborated by Reinhold [9]: fluctuating selection can maintain polymorphisms if the polymorphism is sex-limited.

Frequently, colour polymorphism is restricted to one sex as for example in the lizard Uta stansburiana. These lizard morphs follow different life history strategies and a trade- 
off between immunity and population density has been identified, such that the decline in antibody responsiveness with an increased number of neighbors is morph dependent $[10,11]$.

In insects female colour polymorphisms are widespread among damselflies, such as polymorphism in female coenagrionids (Zygoptera, Odonata). Usually one female morph resembles the male, dubbed the andromorph, while one or more other "typical" female morphs are called gynomorphs [12]. This polymorphism has been shown to be heritable in at least three coenagrionid species [13-16] and is most likely to be the case in all coenagrionids.

Several hypotheses to explain the evolution and maintenance of female polymorphism in damselflies have been suggested. These explanations are, with few exceptions solely based on observations on mating behavior and most studies do not include any data on fitness or fitness components. Few studies have linked their results to the general theories for the maintenance of these polymorphisms $[8,9,17]$ and even fewer have investigated correlations between coloration and other physiological or life history traits [18].

Broadly these damselfly-specific ideas fall into two categories: (i) the density dependent/male mimic hypothesis $[12,19]$ or (ii) the learned mate recognition hypothesis (LMR) [[20] and references therein] or variations on them [e.g. [21]]. Coenagrionids have a non-territorial mating system with a high rate of male harassment. Copulations can last several hours and females are forced to mate several times, even though they could store enough sperm to fertilize their entire egg number from only one mating [22]. The male mimic hypothesis states that andromorphs mimic males to avoid male harassment with the risk of no matings under low population densities [19]. In contrast, according to the LMR idea males learn to recognize the most common morph in the population, which usually is the andromorph [[23], but see [24]] and therefore the less common morph can avoid harassment. Svensson et al. [25] recently showed that frequency-dependent selection maintains the polymorphism in the wild in Ischnura elegans. They combined extensive field sampling with a population genetic model and concluded that fecundity differences between the three female morphs are sufficient to maintain the polymorphism via frequency-dependent selection. Their analysis was based on the assumption that sexual conflict underpins the fecundity differences, however the sexual conflict was not demonstrated.

If female morph is correlated with other traits such as life history traits or physiological traits, than selection on these traits will affect morph frequencies. Fluctuating selection on such traits can be strong enough to maintain sex-limited polymorphisms [9]. This happens, because the disfavoured loci are shielded from selection in the mono-morphic sex. In damselflies morph differences in life history and related traits have hardly been studied. However, differences between female morphs in survivorship [26], and development time have been reported [18] and in other species such life history difference are reflected in differences in immune function. Here, we use the azure damselfly Coenagrion puella which has three different female morphs, an andromorph (blue), a gynomorph (green) and an intermediate (blue-green), as the study species. We propose that female colour polymorphism could be related to immune function and that selection on immune function and melanism could contribute to the maintenance of the colour polymorphism. There are five independent findings that make this hypothesis an interesting scenario to study, (a) Coenagrion puella shows a sex difference in investment in immune function during the larval stage [27] and in resistance to parasites [28]. C. puella females have a higher haemocyte load and a higher activity of the enzyme Phenoloxidase (PO), a common pattern in many insects [29].

Haemocyte load and PO are important components of insect immune function [30]. Both of these immune defense traits have frequently been linked to higher resistance in insects [31-33]. (b) Female C. puella have larger black cuticular patterning (melanin) on their abdomens when compared to males, however there are no differences between the female morphs [G. Joop, unpublished data]. The PO cascade is involved in the melanization and sclerotization of the cuticle [30]. This is particularly important for defense against fungal infections, as entomopathogenic fungi hydrolyze cuticular proteins [30]. (c) It has been reported that mating frequencies differ between the female morphs in several species [see references in [20]]. In the damselfly Matrona basilaris japonica it was shown that mating reduced encapsulation of artificial antigens in a wild population [34]. (d) Development time is related to investment in immune function in damselflies [35], such that faster development results in lower investment into immune function. Different life histories, such as morph specific survival rates [26] and development rates [18] are likely to select for different investment in immune function $[29,36]$. (e) Because immune function is the mediator of parasitic impact and wound repairs, it is likely to be an important indirect fitness trait [37].

Here we aim to elucidate the relationship between colour polymorphism and immune function in order to understand the maintenance of colour polymorphisms. We expect the female morphs to differ from males and differences between the female morphs are also likely. Specifi- 
Table I: MANCOVA (Pillai's trace) for immunity as measured by PO activity and haemocyte counts and condition for the different 'colour classes' (males, blue, bluegreen and green females) and populations in 2003, controlling for size (fatless weight).

\begin{tabular}{lccccc}
\hline \multicolumn{1}{c}{ source } & value & F & Hypothesis df & Error df & P \\
\hline 'colour class' & 0.147 & 3.870 & 9 & 675.00 & $<0.001$ \\
population & 0.127 & 10.783 & 3 & 223.00 & $<0.001$ \\
'colour class' x population & 0.095 & 2.457 & 9 & 675.00 & 0.009 \\
fatless weight & 0.972 & 2457.220 & 3 & 223.00 & $<0.001$ \\
\hline
\end{tabular}

cally we investigated whether the three female morphs [38] and/or the males differ in (i) immunity in adults or (ii) resistance to a novel pathogen in adults infected after emergence (tenerals) and (iii) whether there is any indication for differential resistance in the field to two prevalent natural parasites.

\section{Results}

\section{Immune parameters and condition}

We first analysed whether adult males and females differ in immune function and condition. A MANCOVA (Table 1) revealed that colour classes, males were treated as 'colour class' in this analysis, as well as populations differed in immunity and condition. The between subjects tests (Table 2) showed, that the populations differ only in condition but not in immune parameters. However, we found a significant interaction between population and colour class for PO activity. All female morphs group together and differ from the males (Table 3), except for dry weight and fat content, where the intermediate females differ neither to the other female morphs nor to the males. Overall, PO activity, haemocyte load, dry weight and fat content were always higher in females (Fig. 1). Subsequently we repeated the same analyses, but excluded the males. We did not find differences between female morphs in PO activity, haemocyte load, dry weight or fat content ( $p>0.5$ in all cases).

\section{Fungal infection experiment}

First we tested whether males and females differ in their survival, which is highly significant for $\operatorname{sex}(\mathrm{n}=378, \mathrm{Z}=$ 3.84, $\mathrm{p}=0.00012)$ and treatment $(\mathrm{n}=378, \mathrm{Z}=-4.67, \mathrm{p}<$ 0.0001 ) (Fig. 3a), therefore fungal treatment reduced survival differently depending on sex, and females survived better. In a second analysis we tested for survival differences between the different female morphs (Fig. 3b). Again the fungal treatment has an influence on survival ( $\mathrm{n}$ $=159, \mathrm{Z}=-2.263, \mathrm{p}=0.024$ ) but between the female morphs no significant differences were found $(n=159, Z$ $=-0,998, p=0.320$ ). In a third model we used treatment and colour morph including males as covariates. Both covariates were significant $(n=378$, colour morph: $\mathrm{Z}=$ $3.72, \mathrm{p}=0.0002$, treatment: $\mathrm{Z}=-4.53, \mathrm{p}<0.0001)$. Subsequently we compared the first model (only gender differences) with the third model (that included female colour morphs and males). However, we did not find a difference in the performance of these models (Difference in AIC between model 1 and 3: as this is $>2$, the models do not differ). The differences in general colour morph in model 3 are explained by the differences between males and females alone.

\section{Natural parasites}

We did not find a difference in water mite or gregarine abundance for the 'colour classes' (note that males were entered as colour class in the statistical model) (Table 4).

Table 2: Tests of between subjects effects for immunity as measured by PO activity and haemocyte counts and condition for the different 'colour classes' (males, blue, bluegreen and green females) and populations in 2003.

\begin{tabular}{llllc}
\hline \multicolumn{1}{c}{ source } & dependent variable & df & F & P \\
\hline 'colour class' & PO activity [In] & 3 & 7.535 & $<0.001$ \\
& haemocytes [sqrt] & 3 & 4.593 & 0.004 \\
& dry weight & 3 & 2.903 & 0.036 \\
fat content & 3 & 2.903 & 0.036 \\
population & PO activity [In] & 1 & 1.376 & 0.242 \\
& haemocytes [sqrt] & 1 & 3.226 & 0.074 \\
'colour class' X population & dry weight & 1 & 28.106 & $<0.001$ \\
& fat content & 1 & 28.106 & 0.001 \\
& PO activity [In] & 3 & 3.048 & 0.030 \\
& haemocytes [sqrt] & 3 & 2.422 & 0.067 \\
& dry weight & 3 & 1.790 & 0.150 \\
\end{tabular}


Table 3: Pairwise comparisons of immunity as measured by PO activity and haemocyte counts and condition for the different 'colour classes' (males, blue, blue-green and green females).

\begin{tabular}{|c|c|c|c|c|c|}
\hline dependent variable & 'colour class' (I) & 'colour class' (2) & $\begin{array}{c}\text { mean difference } \\
(1-2)\end{array}$ & SE & $\mathbf{P}$ \\
\hline \multirow[t]{6}{*}{ PO activity [ln] } & blue female & green female & 0.579 & 0.0531 & 0.277 \\
\hline & & intermediate female & 0.265 & 0.0568 & $0.64 I$ \\
\hline & & male & 1.860 & 0.0542 & 0.001 \\
\hline & green female & intermediate female & -0.314 & 0.0395 & 0.428 \\
\hline & & male & 1.281 & 0.0364 & 0.001 \\
\hline & intermediate female & male & 1.595 & 0.0405 & $<0.001$ \\
\hline \multirow[t]{6}{*}{ haemocyte [sqrt] } & blue female & green female & 0.120 & 0.0431 & 0.781 \\
\hline & & intermediate female & 0.469 & 0.0462 & 0.311 \\
\hline & & male & 1.133 & 0.0441 & 0.011 \\
\hline & green female & intermediate female & 0.348 & 0.0321 & 0.279 \\
\hline & & male & 1.013 & 0.0296 & 0.001 \\
\hline & intermediate female & male & 0.665 & 0.0330 & 0.045 \\
\hline \multirow[t]{6}{*}{ dry weight [mg] } & blue female & green female & -0.028 & 0.045 & 0.533 \\
\hline & & intermediate female & -0.046 & 0.048 & 0.338 \\
\hline & & male & -0.106 & 0.046 & 0.022 \\
\hline & green female & intermediate female & -0.018 & 0.034 & 0.590 \\
\hline & & male & -0.078 & 0.031 & 0.012 \\
\hline & intermediate female & male & -0.060 & 0.034 & 0.083 \\
\hline \multirow[t]{6}{*}{ fat content [mg] } & blue female & green female & -0.028 & 0.045 & 0.533 \\
\hline & & intermediate female & -0.046 & 0.048 & 0.338 \\
\hline & & male & -0.106 & 0.046 & 0.022 \\
\hline & green female & intermediate female & -0.018 & 0.034 & 0.590 \\
\hline & & male & -0.078 & 0.031 & 0.012 \\
\hline & intermediate female & male & -0.060 & 0.034 & 0.083 \\
\hline
\end{tabular}

Water mite infestation differs between the populations in 2003 with hardly any water mites present in population 2 . In general, infestation with these parasites seems not to be very high and with only slight differences for water mites between 2003 and 2004 (Fig. 2).

\section{Discussion}

We found significant differences between adult male and female Coenagrion puella from the wild, with females having a stronger immune function as indicated by the higher haemocyte counts and PO activity. Moreover, teneral females were more resistant against fungal infection with
M. anisopliae than males. However, we did not find any such differences between the female morphs. We found no evidence for any differences in parasite abundance in the field, neither between the sexes nor within the female colour morphs. Why do females invest more in resistance and immunity? And why are there no differences between the female colour morphs?

Adult females have generally a higher PO activity and a higher haemocyte load than the adult males in C. puella. Therefore our results support the data of Joop and Rolff [27], where the sexes differed in their investment in

Table 4: Analyses (ANCOVAs) of the mean numbers of water mites in 2003 and 2004 and for the mean number of gregarines in 2004 in Coenagrion puella males and females (coded as colour class). In all three analyses body size was accounted for by using head width as a covariate.

\begin{tabular}{|c|c|c|c|c|}
\hline Year and parasite & source & df & $\mathbf{F}$ & $\mathbf{P}$ \\
\hline \multirow[t]{4}{*}{ 2003, water mites } & 'colour class' & 3 & 0.605 & 0.612 \\
\hline & population & 1 & 12.201 & 0.001 \\
\hline & 'colour class' × population & 3 & 1.886 & 0.682 \\
\hline & head width & 1 & 8.397 & 0.004 \\
\hline \multirow[t]{2}{*}{ 2004, water mites } & 'colour class' & 3 & 2.261 & 0.082 \\
\hline & head width & 1 & 11.428 & 0.001 \\
\hline \multirow[t]{2}{*}{ 2004, gregarines } & 'colour class' & 3 & 0.419 & 0.740 \\
\hline & head width & I & 0.024 & 0.877 \\
\hline
\end{tabular}



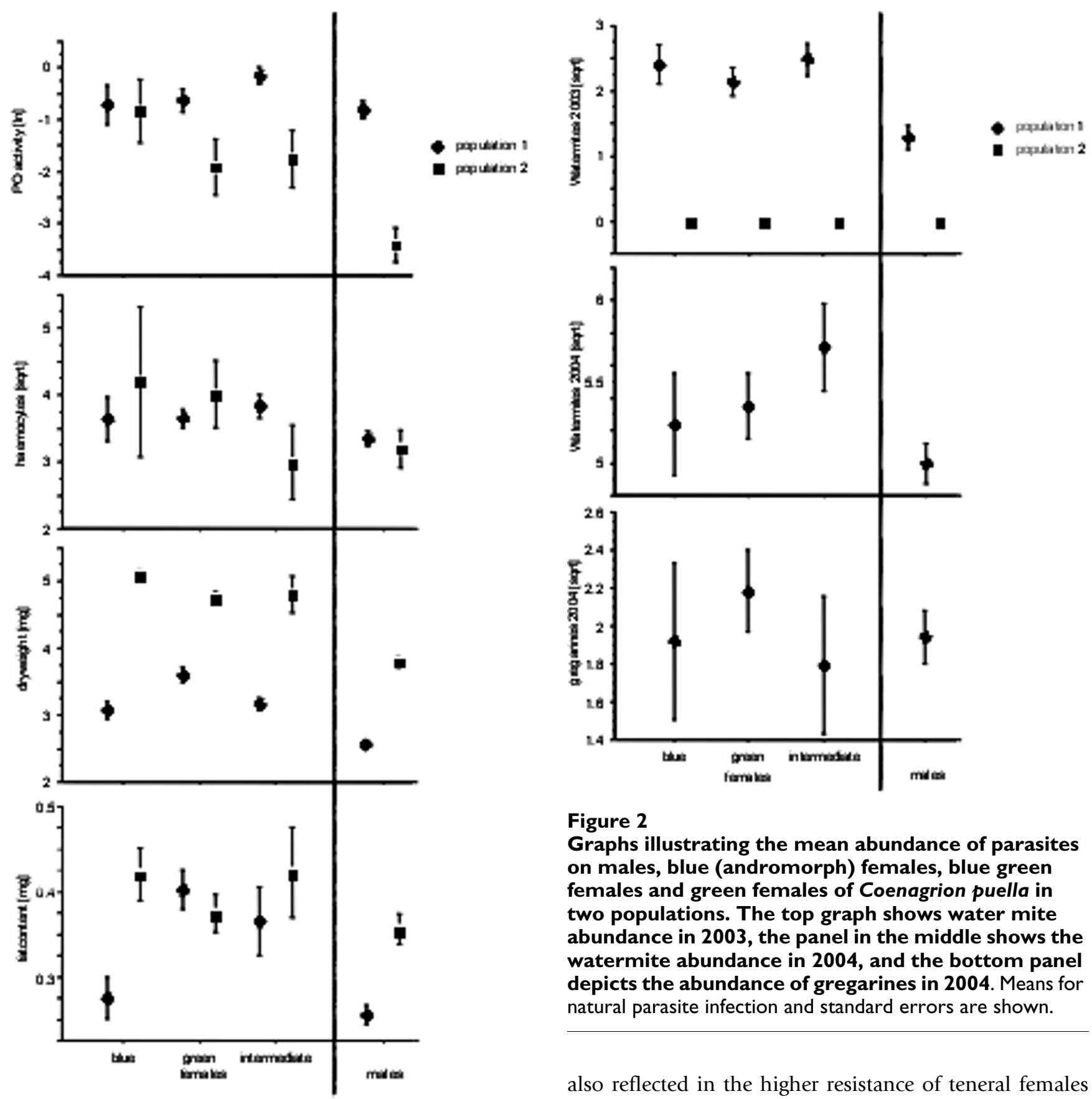

Figure 2

Graphs illustrating the mean abundance of parasites on males, blue (andromorph) females, blue green females and green females of Coenagrion puella in two populations. The top graph shows water mite abundance in 2003, the panel in the middle shows the watermite abundance in 2004 , and the bottom panel depicts the abundance of gregarines in 2004. Means for natural parasite infection and standard errors are shown.

Figure I

Graphs illustrating the differences in immune parameters (two top panels), size (third panel from top) and condition (bottome panel) between males, blue (andromorph) females, blue green females and green females of Coenagrion puella in two populations.

Shown are means and standard errors.

immunity immediately after emergence in $C$ puella. This also shows that the sexual dimorphism is maintained later in the adult life. The differences in immune function were

also reflected in the higher resistance of teneral females against the fungal pathogen. Female $C$. puella have a higher black melanin content in their cuticle than males (G. Joop unpublished data). Black patterning of insect cuticle is commonly a product of melanin, a pigment, that has antimicrobial properties and which is produced via the PO cascade [30,32]. Wilson et al. [39] have shown that melanic moths exhibit a higher resistance towards entomopathogenic fungi than non-melanic individuals. $M$. anisopliae and most other entomopathogenic fungi of the order Cordyceps have spores that produce a lysozyme which dissolves the insect's cuticle [40]. The spores can then enter the haemocoel and parasitise the host [41]. The 


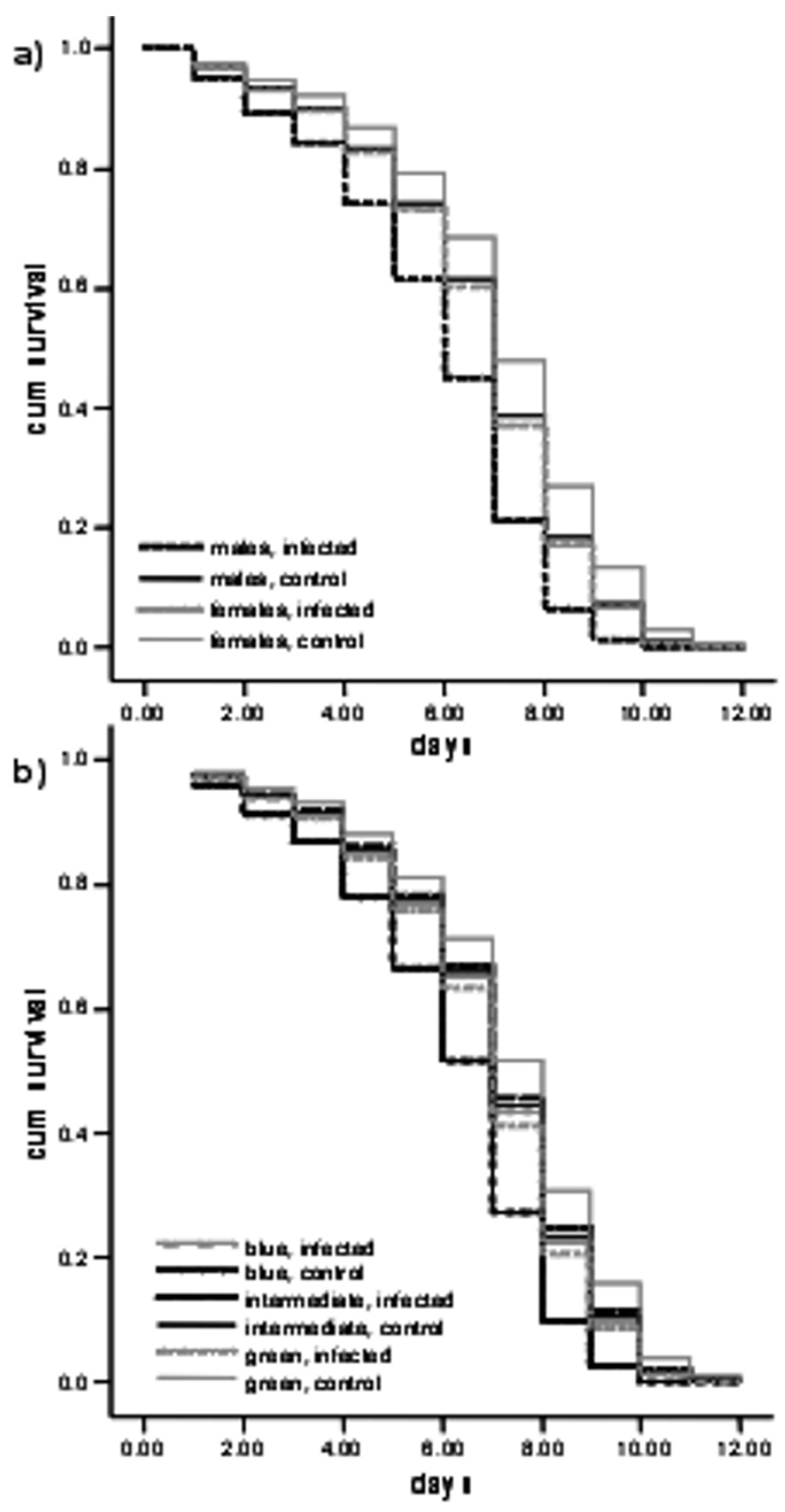

Figure 3

Survival of Coenagrion puella in two populations after fungal infection and for non-infected controls, a) comparing males and all females, b) comparing the different female morphs.

fact that all female morphs invest more in PO than males, which is most likely involved in resistance against the fungal infection [30], make a trade-off between PO activity and cuticular melanization unlikely. It was recently shown that PO responds in positive correlated fashion to selection on cuticular darkness in the mealworm beetle [42]. It could be speculated that in other coenagrionid damselfly species such as Ischnura elegans, where males and females are almost similar in black patterning, no such differences in fungal resistance occur. If this holds true, it would constitute a potential cost of being a nearly perfect male mimic in C. puella: females would forfeit their higher resistance by decreasing their black melanin content.

The differences in immune function and resistance between the sexes can be explained by differences in lifehistory, males increase their fitness by increasing their mating rate while females increase their fitness by longevity $[29,43-45]$. Furthermore females have a much higher investment in reproduction than males, as egg production is much more energy consuming than the production of sperm [46]. Because females achieve higher fitness through longevity and pay higher costs for reproduction, they should invest optimally in immunity as well to ensure a long reproductive life.

An additional selection pressure on black patterning may be found in thermoregulation. The mortality of mitosporic fungi such as M. anisopliae has been shown to be highly dependent on the environmental temperature and therefore the insect's body temperature $[47,48]$. Locusts use this and actively seek places with higher temperature after fungal infection in order to overcome it [48]. Male $C$. puella spend most of their time near the water waiting for females, while females spend more time searching for prey and resting in hedges [49]. Therefore males are probably exposed to higher temperatures than females. The higher black content might help the female to gain higher body temperature while being exposed to the sun. Furthermore, it has been suggested that male C. puella are capable of thermoregulatory colour change [38]. This thermoregulation is assumed to protect flight muscles and sperm from overheating. Therefore it could be, that female cuticle does not simply have a higher black melanin content, but that reduced melanin patterning in males is adaptive to avoid overheating. With the more complex structure of the female cuticle due to the higher melanin content, the cuticle might also give additional UV protection but certainly more data on this would be needed.

Blue females are dubbed andromorphs [12] and also are supposed to mimic male behaviour to avoid male harassment [12,50-52], why did we find no differences in immune defence between the female morphs? As all females have the same reproductive requirements in terms of for example egg production and oviposition, this might outweigh any behavioural differences between the morphs. Studies in related coenagrionid species have reported differences in life histories such as survival [26] and development time [18], traits that have been shown to be linked to immune function in other studies [35] and here with respect to gender differences in resistance 
against fungal infections. Contrary to our expectations the supposed different mating tactics in the female morphs do not seem to mirror different immune strategies, as reported in the female polymorphic lizard $U$. stansburiana [11]. Longevity should of course be the overriding factor, but it seems that this is not achieved by different strategies involving immunity and resistance. It is noteworthy, that we sampled adult individuals in the wild. Therefore differences in survival selection during the pre-reproductive stage could potentially obscure differences in immune function, if survival and immune function during this stage are correlated. Further studies are needed to disentangle these possibilities and to account for potential morph differences in plasticity of immune function as well. An indicator for plasticity in immune function in the wild is our result that shows an interaction between colour class and population for PO activity. We have no data that explain these differences, possible explanations include genetic differences between the populations or different diets.

From a broader perspective this is supported by our results for parasitism in the wild. We found no significant differences overall for water mite or gregarine load. Taking into account the fact that all damselfly larvae (both sexes and all female morphs) hatch and move to more shallow areas of the pond inhabited by potentially infecting water mites, it is not surprising that we found no differences in parasite load between gender or morphs [53]. Gregarines are ingested with the food, either in the larval or adult stage. And as long as the food infected is equally distributed over the population's habitat and they eat the same food types, it is not surprising that no differences in parasite load were found. As a next step it should be studied whether the parasites differ in their effect on the female morph's longevity: Braune and Rolff [28] demonstrated that the males and females C. puella differed in their survival, which was also dependent on water mite load. Furthermore females need to obtain more food because of the expenditure upon egg production. Therefore females have an increased risk of gregarine infection. In other damselfly species it has been shown that PO activity is positively correlated with resistance against gregarines [54] and that gut and haemolymph PO activity is positively correlated [55]. Even though we have no data on this link in C. puella, one possible explanation is that females have a higher gregarine infection risk, yet because of their higher investment in immunity this is not reflected in the abundance of gregarines in hosts in the wild.

\section{Conclusion}

In conclusion, our results do not support the idea that blue females of $C$. puella are male like with respect to immunity and resistance. This is probably due to the selection pressure upon female morphs to have the same reproductive level. Differences in immune function are unlikely to underpin fluctuating selection on polymorphism in the wild sensu [9], unless morph differences in life history [18] translate in to differences in immune function in the wild given the tenet that immunity in damselflies is plastic $[27,35]$. It is likely that the female morphs have different costs associated with maintaining this standard level of reproduction and therefore have to trade-off elsewhere, e.g. in clutch- or egg size, especially as reproduction seems to be of overriding importance.

\section{Methods \\ Study organism}

Coenagrion puella (Zygoptera, Odonata) is a common and well studied species $[27,28,44,45]$ of northern and central Europe, usually occurring in small ponds [56]. Larvae hibernate in later instars. Shortly before emergence the damselfly larvae move to shallow water regions, where water mites might settle onto them, while they only later attach to the adult and start parasitizing [57]. As damselflies keep on feeding after emergence they may become infested with endoparasites as well e.g. eugregarines, as has been shown for several other damselfly species [e.g. $[54,58]]$. These endoparasites attach to the mid-gut epithelium, thus rupturing or blocking it [60]. After adult emergence it is easy to distinguish the sexes but not the female colour morphs, as the individuals are not yet coloured. Becoming fully coloured and sexually mature takes, depending on weather conditions, seven to ten days, however the colour morph is detectable after two to three days. For C. puella three female colour morphs are described [38] an 'andromorph' (blue), a 'gynomorph' (green) and an 'intermediate' morph (blue-green).

\section{Immune parameters and condition}

Damselflies were collected as adults from two different populations near Braunschweig, Lower Saxony, Germany, over the whole flight season 2003. Population 1 is a well established population of high density and older than 15 years while population 2 is not older than three years and is of lower density [Joop, pers. obs.]. The populations are $9 \mathrm{~km}$ apart, separated by a motorway and therefore almost certainly far enough to prevent gene flow. We used only fully coloured and therefore sexually mature animals but made sure that they were not too old by checking their wings for damage and stiffness $[11,22]$ : those with damaged wings were excluded. Furthermore animals were checked for scars resulting from previously attached water mites If there were scars but no water mites the damselfly has mated at least once (Arrenurus water mites detach during oviposition, [57]) and they were excluded from the analysis. 


\section{Immune parameter}

As immune parameters we measured PO activity (humoral immunity) and counted haemocytes (cellular immunity), for both we followed the protocol of Joop and Rolff [27]. To obtain the haemolymph, the damselfly's thorax was perfused with $0.3 \mathrm{ml}$ sodium cacodylate buffer (0.01 M Na-Coc, $0.005 \mathrm{M} \mathrm{CaCl}_{2}$ ). $20 \mu \mathrm{l}$ of the resulting solution was pipetted into one well of a multiwell slide (adhesive epoxy-coated 12-well slides, Roth L209.1) to estimate the number of haemocytes. Haemocytes were stained with DAPI and counted using and image analysis system as described in [35].

The rest of the haemolymph sample was frozen at $-80^{\circ} \mathrm{C}$ to disrupt cell walls and stop enzyme function. To measure PO activity $40 \mu \mathrm{l}$ of the frozen haemolymph sample was defrosted and mixed with $100 \mu$ l distilled water, $20 \mu \mathrm{l}$ phosphate buffered saline (PBS) and $40 \mu \mathrm{l}$ I-DOPA (4 g/ $\mathrm{ml}$ ) as the substrate in 96 well cell culture plates. Samples were measured every 15 seconds over 30 minutes at $30^{\circ} \mathrm{C}$ and at a wavelength of $490 \mathrm{~nm}$. The slope of the reaction was calculated using softmax pro software and $\mathrm{V}_{\text {max }}$ the velocity of maximum substrate conversion, was recorded.

\section{Condition}

We measured dry weight and fat content as correlates of condition. Both have been shown to be good estimates of condition in C. puella [60]. As females store the eggs in their abdomen and therefore have a higher weight and fat content in this compartment, we only analysed the condition parameter for the thorax in order to have a better comparison between the sexes. Measurements were taken according to Joop and Rolff [27] and to correct for size, fatless weight was used.

\section{Statistical analyses}

As our estimates for immune function and condition were highly correlated these data were analysed using a MANCOVA with fatless weight as covariate. Fatless weight is a better correction for size than head width and therefore should be used whenever possible. Number of haemocytes (square root transformed [61]), PO activity (Intransformed [61]), dry weight and fat content were used as dependent variables, 'colour morph' (male; blue, green or blue-green females) and population (1 or 2) as factors. The MANCOVA was followed by tests of between-subjects effects and pairwise comparisons. All analyses were performed using SPSS 12.0.1.

\section{Fungal infection experiment}

Damselfly larvae were caught in the first two weeks in April 2004 in the area "Klei" near Braunschweig (Lower saxony, Germany, $52^{\circ} 21^{\prime} \mathrm{N}, 10^{\circ} 35^{\prime} \mathrm{E}$ ), when they were in the final three instars. Larvae were randomly placed into one of eight tanks (length:width $36: 30 \mathrm{cms}$, filled with 18 litres of de-chlorinated water). Fifty larvae were placed in each tank. Plastic mesh was provided as a climbing structure, allowing the larvae to leave the water for hatching. Tanks were a priori assigned to control or fungal treatment. Tanks were placed in a temperature controlled room at $16^{\circ} \mathrm{C}$ and a light-cycle of $12: 12 \mathrm{~h}$. All damselflies were held under the same feeding conditions. Tanks were monitored every morning for eclosing individuals, the first adult damselflies were found on $17^{\text {th }}$ June 2005 .

As a fungal pathogen we used Metarrhizium anisopliae, which is known to be an entomopathogenic fungus [62]. Spores of $M$. anisopliae attach to the insect's cuticle and grow through the cuticle. Several fungi are known to attack damselflies $[40,63]$, but $M$. anisopliae is not a natural pathogen of $C$. puella. We chose this novel pathogen because we were interested in resistance and not host-parasite co-evolution.

\section{Spore suspension of $M$. anisopliae}

M. anisopliae (strain F142) was grown on PDA (Potato Dextrose Agar, Merck) and later on $2 \%$ biomalt agar for better sporulation at $25^{\circ} \mathrm{C}$ in petri dishes. To obtain the hydrophobe spores a $0.05 \%$ Triton $\times 100$ suspension was pipetted onto the petri dish, spores wiped off and their concentration adjusted using a Thoma haemocytometer [64]. Spore concentrations were between $1.4 \times 10^{7}$ and 3.0 $\times 10^{7}$ spores per $\mathrm{ml}$. Spore suspensions were stored in the fridge for no longer than $24 \mathrm{~h}$ before use [41].

\section{Inoculation with M. anisopliae}

Imaginally eclosed damselflies were collected every morning. Their head width as a measure of size [45] and the fresh weight were recorded. The abdomen of control individuals was dipped in microcentrifuge tubes each containing $1.5 \mathrm{ml}$ Triton-X-100, while treatment individuals were dipped in $1.5 \mathrm{ml}$ spore suspension (in Triton-X-100). Adult damselflies were held in $500 \mathrm{ml}$ plastic containers with wet filter paper to provide humidity. Containers were closed with gauze. To prevent cross-infection inoculated treatment damselflies were kept in a separate $1 \mathrm{~m}^{3}$ glass cube. To have optimal starting conditions for the spores to grow, all animals were kept for $8 \mathrm{~h}$ at $27^{\circ} \mathrm{C}$ [64]. Thereafter damselflies were kept at $16^{\circ} \mathrm{C}$, which is the ideal temperature to keep them alive as long as possible without feeding [Joop, unpublished data]. Under bad weather conditions damselflies can survive in the wild without hunting for several days [20] so our experimental conditions are not unnatural in this respect. Furthermore under bad weather conditions, especially rainy but not too cold (above $10^{\circ} \mathrm{C}$ ) weather fungal growth is higher [62] and therefore damselflies are most likely to struggle with fungal infections. Survivorship was recorded daily. Dead damselflies were collected and their surface sterilized using 70\% Ethanol and sterile distilled water. These dam- 
selflies were subsequently put into a sterile petri dish with humid filter paper and checked after 2, 4 and 6 weeks for fungal growth and whether this was M. anisopliae. This was necessary to make sure that the fungal infection worked and to control the control individuals for fungal growth as well.

\section{Statistical analyses}

Survival was analysed using a Cox regression as implemented in R [65]. As all animals died our data are noncensored. Days to death were used as a time estimate and treatment (control, infected) and 'colour morph' (male; blue, green or blue-green female) or sex (male, female) as co-variates. The performance of the models is compared using AIC [65].

\section{Natural parasites}

Water mites are known to be common ectoparasites of damselflies, of which Arrenurus cuspidator is the most common in C. puella at least in one of our study populations [53]. They only parasitze adult individuals but attach in the larval stage [57]. In order to get an accurate estimate of the abundance of parasitic water mites we counted the parasitizing water mites on the damselflies collected as above for the two different populations in 2003. In 2004 water mites were only counted for population 1 . Damselflies that showed scars were excluded, as the number of parasitic mites could not be estimated accurately. However, this is also another indicator of age, as they have to have mated before (see [57] and references therein).

Other common parasites in damselflies are gregarines [54], which parasitise in the mid-gut. Gregarines have so far not been described for $C$. puella. Therefore we collected age-controlled (see above) individuals of $C$. puella from population 1 in 2004 and dissected their mid-gut [see [54]]. In the dissected animals water mite numbers were also counted.

\section{Statistical analyses}

To control for a potential relationship between body size and parasite abundance, head width was measured and included into analyses, of both, water mites and gregarines, as a covariate. We found no correlation between the numbers of different parasites and therefore analysed them separately using ANCOVAs with number of parasites (square root transformation yielded a distribution sufficient to use ANOVA [61]) as the dependent variable and colour morph and population (2003 data only) as factors. All analyses were performed using SPSS 12.0.1.

\section{Authors' contributions}

Animals were collected and reared in the lab by GJ. The immune assays were performed by GJ, while AM adapted the fungal infection experiment to damselflies and con- ducted the classical and molecular microbiological methods to control for cross-infection in this experiment. JR and MSJ participated in design and coordination of the study. GJ and JR analysed the data and wrote the paper, JR revised the paper.

\section{Acknowledgements}

Many thanks to Siegfried Draeger for help and advice with the fungi and to Axel Conrad for helping in the field. Andrew Beckerman gave kind advice on statistics. Comments by anonymous reviewers greatly improved the presentation of the ms. Thanks to Erik Svensson for access to his paper in press and to Sophie Armitage for comments on an earlier draft. GJ was supported by a Studienstiftung des Deutschen Volkes fellowship. JR was supported by the Natural Environmental research council.

\section{References}

I. Munday PL, Eyre PJ, Jones GP: Ecological mechanisms for coexistence of colour polymorphism in a coral-reef fish: an experimental evaluation. Oecologia 2003, 442:519-526.

2. Galeotti P, Rubolini D, Dunn PO, Fasola M: Colour polymorphism in birds: causes and functions. J Evol Biol 2003, I 6:635-646.

3. Wente WH, Phillips JB: Fixed green and brown color morphs and a novel color-changing morph of the pacific tree frog Hyla regilla. Am Nat 2003, I 62:46I-473.

4. Quigley IK, Turner JM, Nuckels RJ, Manuel JL, Budi EH, MacDonald EL, Parichy DM: Pigment pattern evolution by differential deployment of neural crest and post-embryonic melanophore lineages in Danio fishes. Development 2004, | 3 |:6053-6069.

5. Losey JE, Ives AR, Harmon J, Ballantyne F, Brown C: A polymorphism maintained by opposite patterns of parasitism and predation. Nature 1997, 388:269-272.

6. Andersson M: Sexual Selection Princeton University Press; 1994.

7. Kodric-Brown A: Female preference and sexual selection for male coloration in the guppy (Poecilia reticulata). Behav Ecol Sociobiol 1985, I 7:199-205.

8. Hartl D, Clark A: Principles of population genetics Sinauer; 1997.

9. Reinhold K: Maintenance of a genetic polymorphism by fluctuating selection on sex-limited traits. J Evol Biol 2000, 13:1009-1014.

10. Sinervo B, Bleay C, Adamopoulou C: Social causes of correlational selection and the resolution of a heritable throat color polymorphism in a lizard. Evolution 200 I, 55:2040-2052.

II. Svensson E, Sinervo B, Comendant T: Density-dependent competition and selection on immune function in genetic lizard morphs. Proc Nat Acad Sci USA 200 I, 98: I 256 I-I 2565.

12. Robertson HM: Female dimorphism and mating behaviour in a damselfly, Ischnura ramburi: females mimicking males. Anim Behav 1985, 33:805-809.

13. Johnson C: The inheritance of female dimorphism in the damselfly, Ischnura damula. Genetics 1964, 49:513-519.

14. Johnson C: Genetics of female dimorphism in Ischnura demorsa. Heredity 1966, $21: 453-459$.

15. Cordero A: The inheritance of female polymorphism in the damselfly Ischnura graellsii (Rambur) (Odonata: Coenagrionidae). Heredity 1990, 64:341-346.

16. Andres JA, Cordero A: The inheritance of female colour morphs in the damselfly Ceriagrion tenellum (Odonata, Coenagrionidae). Heredity 1999, 82:328-335.

17. Leimar O: The evolution of phenotypic polymorphism: randomized strategies versus evolutionary branching. Am Nat 2005, 165:669-68।.

18. Abbott J, Svensson E: Phenotypic and genetic variation in emergence and development time of trimorphic damselfly. J Evol Biol 2005, I 8: 1464-1470.

19. Hinnekint BON: Population dynamics of Ischnura E. elegans (Vander Linden) (Insecta:Odonata) with special reference to morphological colour change, female polymorphism, multiannual cicles and their influence on behaviour. Hydrobiologia 1987, |46:3-3| 
20. Fincke OM: Polymorphic signals of harassed odonates and the males that learn them support a novel frequency-dependent model. Anim Behav 2004, 67:833-845.

21. Sherratt TN: The evolution of female-limited polymorphisms in damselflies: a signal detection model. Ecol Lett 200 I, 4:22-29.

22. Corbet PS: Dragonflies - behaviour and ecology of Odonata Harley Books; 1999.

23. Miller $M N$, Fincke OM: Cues for mate recognition and the effect of prior experiences on mate recognition in Enallagma damselflies. J Insect Behav 1999, | 2:80|-8|4.

24. Forbes $M$ : Test of hypotheses for female-limited polymorphism in the damselfly, Enallagma boreale Selys. Anim Behav 1994, 47:724-726.

25. Svensson El, Abbott J, Härdling R: Female polymorphism, frequency dependence, and rapid evolutionary dynamics in natural populations. Am Nat 2005, 165:567-576.

26. Andres J, Cordero A: Survival rates in a natural population of the damselfly Ceriagrion tenellum: effects of sex and female phenotype. Ecol Entomol 200I, 26:34l-346.

27. Joop G, Rolff J: Plasticity of immune function and condition under the risk of predation and parasitism. Evol Ecol Res 2004 6: $1051-1062$

28. Braune $P$, Rolff $\mathrm{J}$ : Parasitism and survival in a damselfly: does host sex matter? Proc R Soc Lond B 200 I, 268: I I 33- I I 37.

29. Rolff J: Bateman's principle and immunity. Proc Roy Soc Lond $B$ 2002, 269:867-872.

30. Gillespie J, Kanost M, Trenczek T: Biological mediators of insect immunity. Annu Rev Entomol 1997, 42:6। I-643.

31. Braun A, Hoffmann J, Meister M: Analysis of the Drosophila host defense in domino mutant larvae, which are devoid of hemocytes. Proc Natl Acad Sci USA 1998, 95: |4337-| 4342.

32. Siva-Jothy MT, Moret $Y$, Rolff J: Evolutionary ecology of insect immunity. Invited review. Adv Insect Physiol 2005, 32: I-48.

33. Schmid-Hempel P: Evolutionary Ecology of insect immune defence. Annu Rev Entomol 2005, 50:529-55 I.

34. Siva-Jothy MT, Tsubaki Y, Hooper R: Decreased immune response as a proximate cost of copulation and oviposition in a damselfly. Physiol Entomol 1998, 23:274-277.

35. Rolff J, van de Meutter F, Stoks R: Time constraints decouple age and size at maturity and physiological traits. Am Nat 2004 , I 64:559-565.

36. Zuk M, Stoehr A: Immune defense and host life history. Am Nat 2002, 160:S9-S22.

37. Rolff J, Siva-Jothy M: Invertebrate ecological immunology. Science 2003, $301: 472-475$.

38. Sternberg K: Coenagrion puella. In Die Libellen Badenwürttembergs, Kleinlibellen (Zygoptera) Edited by: Sternberg K, Buchwald L. Stuttgart: Verlag Eugen Ulmer; 1999:278-287.

39. Wilson K, Cotter SC, Pell K: Melanism and disease resistance in insects. Ecol Lett 200I, 4:637-649.

40. Sung JM: Cordyceps Diversity and its preservation in Korea Inoculum 2004, 55: I-3.

4I. Goettel MS, Inglis GD: Fungy: Hyphomycetes. In Manual Techniques in Insect Pathology Edited by: Lacey L. San Diego: Academic Press; 1999:213-249.

42. Armitage S, Siva-Jothy $M$ : Immune function responds to selection for cuticular colour in Tenebrio molitor. Heredity 2005 , 94:650-656.

43. Bateman AJ: Intra-sexual selection in Drosophila. Heredity 1948 , 2:349-368.

44. Banks $M$, Thompson $D$ : Lifetime mating success in the damselfly Coenagrion puella. Anim Behav 1985, 33: II75-I I83.

45. Banks $M$, Thompson D: Lifetime reproductive success of females of the damselfly Coenagrion puella. J Anim Ecol 1987, 56:8I5-832.

46. Williams G: Adapatation and Natural Selection Princeton Univ. Press; 1996.

47. Stacey DA, Fellowes MDE: Influence of temperature on pea aphid Acyrthosiphon pisum (Hemiptera: Aphididae) resistance to natural enemy attack. Bull Entomol Res 2004, 92:35 I-357.

48. Thomas $M B$, Blanford $S$ : Thermal biology in insect-parasite interactions. Trends Ecol Evol 2003, 1 8:344-350.

49. Anholt B, Vorburger C, Knaus P: Mark-recapture estimates of daily survival rates of two damselflies (Coenagrion puella and Ischnura elegans). Can / Zool 200I, 79:895-899.
50. Cordero A: Reproductive behaviour of Ischnura graellsii (Rambur) (Zygoptera: Coenagrionidae). Odonatologica 1989, I 8:237-244.

51. Van Gossum H, Stoks R, De Bruyn L: Frequency-dependent male mate harassment in intra-specific variation in its avoidance by females of the damselfly Ischnura elegans. Behav Ecol Sociobiol 200I, 5 I:69-75.

52. Sirot LK, Brockmann HJ, Marinis C, Muschett G: Maintenance of female-limited polymorphism in Ischnura ramburi (Zygoptera: Coenagrionidae). Anim Behav 2003, 66:763-775.

53. Rolff J: Water mite parasitism in damselflies during emergence: two hosts, one pattern. Ecography 2000, 23:273-282.

54. Siva-Jothy MI, Plaistow S: A fitness cost of eugregarin parasitism in a damselfly. Ecolo Entomol 1999, 24:465-470.

55. Siva-Jothy MT, Tsubaki Y, Hooper RE, Plaistow SJ: Investment in immune function under chronic and acute challenge in an insect. Physiol Entomol 2001, 26: I-5.

56. Askew RR: The dragonflies of Europe Harley Books; 2004

57. Rolff J: Evolutionary Ecology of water mite - insect interactions: a critical appraisal. Arch Hydrobiol 200I, I 52:353-368.

58. Tsubaki Y, Hooper RE: Effects of Eugregarine parasites on adult longevity in the polymorphic damselfly Mnais costalis Selys. Ecol Entomol 2004, 29:36 |-366.

59. Åbro A: The impact of parasites on adult populations of zygoptera. Odonatologica 1990, 19:223-233.

60. Rolff ], Joop G: Estimating condition: pitfalls of using weight as a fitness correlate. Evol Ecol Research 2002, 4:931-935.

6I. Sokal R, Rohlf F: Biometry WH Freeman and Company; 1995.

62. Domsch KH, Gams W, Anderson TH: Compendium of soil fungi Academic Press; 1980.

63. Czeczuga B, Godlewska A, Mrozek E: Zoosporic fungi growing in dead dragonflies (Odonata). Int Journ Odonatol I999, 2:।87-I97.

64. Barnes A, Siva-Jothy M: Density-dependent prophylaxis in the mealworm beetle Tenebrio molitor L. (Coleoptera: Tenebrionidae): cuticular melanization is an indicator of investment in immunity. Proc Roy Soc Lond B 2000, 267:177-182.

65. Crawley MI: Statistical Computing. An introduction to data analysis using S-Plus John Wiley and Sons; 2002
Publish with Bio Med Central and every scientist can read your work free of charge

"BioMed Central will be the most significant development for disseminating the results of biomedical research in our lifetime. "

Sir Paul Nurse, Cancer Research UK

Your research papers will be:

- available free of charge to the entire biomedical community

- peer reviewed and published immediately upon acceptance

- cited in PubMed and archived on PubMed Central

- yours - you keep the copyright
BiolMedcentral 